\title{
Constraints and Opportunities
}

The Role of Prior Institutions in the Process of

Democratic Consolidation in Taiwan

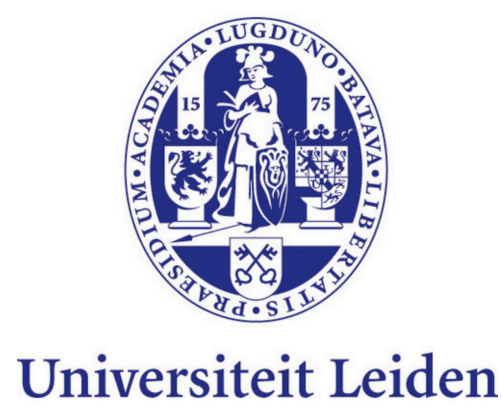

MSc Thesis Political Science

Leiden University

10 June 2013

Koen Rozemeijer

Student ID: 1308297

Supervisor: dr. Daniela Stockmann

Second Reader: prof. dr. Petr Kopecký

Wordcount: 17.622 


\begin{abstract}
Various scholars have addressed the role of past institutions in current developments. Many of those studies have focused on cases in the same geographical regions: Europe and South America. These studies concluded that institutional legacies regularly have a distinct influence on current events, providing constraints and opportunities. This study tests this theory in a region that has been underrepresented in the literature: Asia. By conducting a case study of Taiwan, this research assesses continuities in electoral institutions from the authoritarian era into the process of democratic consolidation. Based on the findings of this examination, this study concludes that the institutional legacies in the political society of Taiwan have had an identifiable but ambiguous impact in the process of democratic consolidation.
\end{abstract}




\section{Table of Contents}

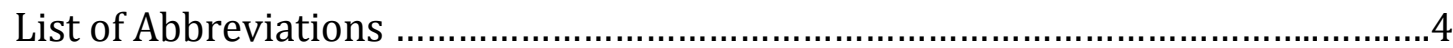

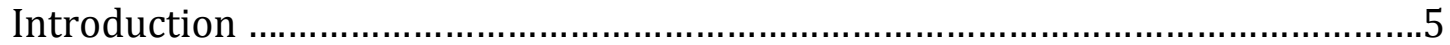

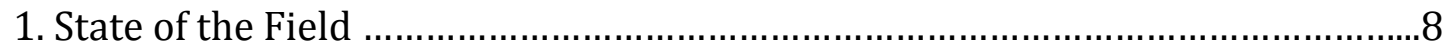

1.1 Democracy as the Only Game in Town ...........................................

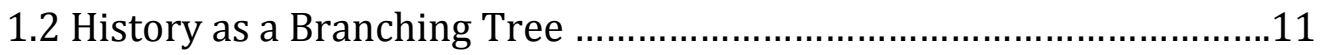

1.3 Institutional Legacies: Constraints and Opportunities ......................13

1.4 Leaving Europe and South America ...............................................22

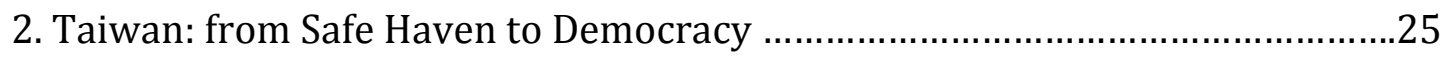

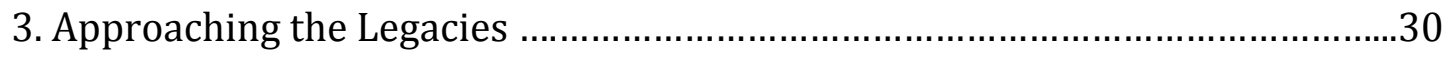

3.1 Taiwanese Elections: Building Blocks for Theory …...........................30

3.2 Institutions from Past to Present ..........................................................32

3.3 Taiwan: a Single-Party Legacy in Asia .................................................34

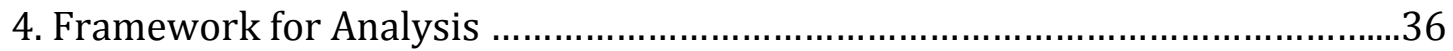

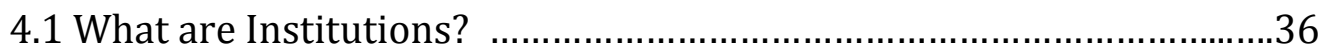

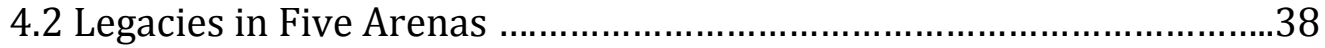

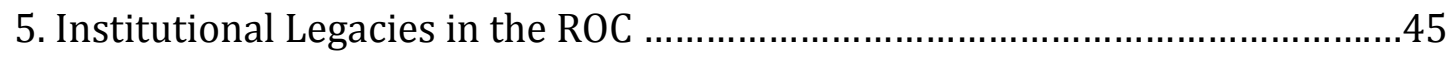

5.1 Electoral Institutions under Authoritarian Rule ...............................45

5.2 Institutional Continuity after the Transition ....................................47

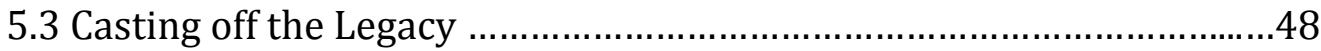

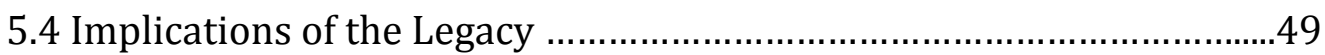

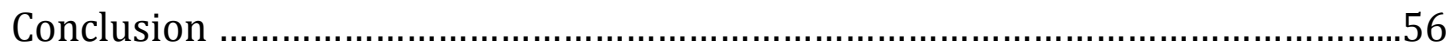

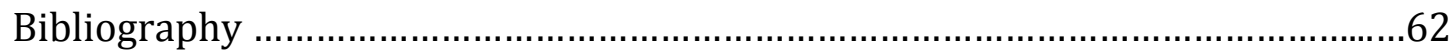




\section{List of Abbreviations}

CC - Control Council

CCP - Chinese Communist Party

DPP - Democratic Progressive Party

KMT - Kuomintang

MMD - Multi-Member Districts

NP - New Party

PFP - People First Party

PRC - People's Republic of China

ROC - Republic of China

SMD - Single Member District

SNTV - Single Nontransferable Vote

TSU - Taiwan Solidarity Union 


\section{Introduction}

In 1991, Samuel Huntington published his famous work on the so-called third wave democracies. He argued that in the 1970s and 1980s, many former authoritarian states in Latin America, Asia, and Eastern Europe had developed into democracies. One of the best-known examples of Asian states that "rode" the third wave and developed into a democracy is the Republic of China (ROC), popularly better known as Taiwan. For decades, the Kuomintang (KMT) had ruled Taiwan. The KMT had retreated to Taiwan after their defeat in the Chinese Civil War to the Chinese Communist Party (CCP), and since 1947 there had been no elections on the national level on Taiwan. But a shift of power started in the 1980s. The KMT decided to let go of the one-party system and to democratize its political system. In 1992, the people of the ROC were able to vote for candidates in the Legislative Yuan, the Taiwanese parliament. The governing party changed for the first time in 2001, when the Democratic Progressive Party (DPP) beat the KMT by 19 seats (Tsai, 2005: 62). From 1996 onwards the citizens could vote for the presidency. In 2000, a DPP candidate won the presidential elections and for the first time in more than sixty years a non-KMT member became president (Solinger, 2001: 30).

The Taiwanese democracy quickly became more consolidated. Opposition parties were no longer forbidden, and regular elections were installed for both the parliament and the position of president. The DPP was the most sizeable opposition party, but in the course of the 1990s several other parties emerged. In the first open elections for the Legislative Yuan in 1992, three parties managed 
to obtain seats, as well as several independent candidates. In the 1998 elections, the number of parties in parliament increased to seven. This increased plurality in the political arena is often seen as an indicator for a consolidating democracy.

The argument put forward in this paper is that institutions installed under authoritarian rule have played a role in the process of democratic consolidation. Some scholars argue that decisions made in the past can be decisive in later events. This theory is called path dependency. In the case of the ROC, this would mean that past decisions of the KMT and institutional choices in the authoritarian era have provided opportunities for democracy and successful democratic consolidation.

An important aspect of democratizing is institutionalization of the democracy. Institutionalization in the context of path dependency can be linked to the concept of institutional legacies. This theory argues that past institutions have an effect on new institutions, in the sense that they provide both constraints and opportunities to the new institution. This is clearly a path dependent theory. Many authors have devoted work to the impact of past institutions and legacies of authoritarian regimes on new democracies (e.g. Angell and Pollack, 1993; Anderson, 1999; Bunce, 2005; Clare, 2007; Pop-Eleches, 2007; Svolik, 2008). Most of the studies of Institutional Legacies focused on Eastern Europe, Southern Europe, or Latin America. The study of institutional legacies in Asia has received less attention though. The impact of institutional legacies in new democracies in Asia might be different from the ones in Europe and South America. There is a gap in the literature here, and a case study of Taiwan will contribute to the theory of institutional legacies. This study tries to answer the following question: 
what was the role of prior institutions in Taiwan's process of democratic consolidation.

This research question is relevant for several reasons. First, more knowledge on factors that provide opportunities or constraints for new democracies are useful for new democracies that try to consolidate their democracy in the future. Newly democratizing states can anticipate when certain institutional characteristics of an authoritarian regime are associated with certain pitfalls or opportunities in the process of democratization. Secondly, this research question engages the scholarly literature on institutional legacies, and contributes to this body of literature by applying this theory in a part of the world that has not received much attention from scholars in this field of study.

This paper is structured as follows: the first chapter will introduce the main concepts and review the literature on institutional legacies. Subsequently, some limitations of this literature are pointed out, followed by the argument set out in this paper. The second chapter will provide a succinct overview of the political history of Taiwan, which helps to understand some of the special characteristics of the case. The third chapter explains which research method is employed in this study, and why this method is chosen. Subsequently, the case and data selection is justified. The fourth chapter explains the framework that is used to study institutional legacies. And lastly, the final chapter will present the findings of this study. First, continuities in institutions after the transition to democracy are explained. Secondly, the implications of these continuities are assessed. The findings are summarized in the conclusion, where they are used to answer the research question. 


\section{State of the Field}

This chapter will discuss the state of the field regarding the literature on institutional legacies and its importance for democratizing states. First, the concepts of democratic consolidation and path dependency will be introduced, followed by a review of the literature on institutional legacies and the importance of those legacies in the process of democratic consolidation. When this is explained, the limitations of the current literature will be pointed out, followed by a summary of the argument put forward in this thesis.

\subsection{Democracy as the Only Game in Town}

Questioning the role of prior institutions in the process of democratic consolidation in Taiwan engages the voluminous body of literature on institutional legacies, and more specifically the literature on institutional legacies in the context of democratic consolidation. Democratic consolidation is a popular topic for political scientists to study (e.g. Diamond, 1993; Lamounier and De Souza, 1993; Diamond, Linz and Lipset, 1995; Valenzuela, 1995; Linz and Stepan, 1996; Diamond, 1999; Haggard and Kaufman, 1999; Schedler, 2001; Markovitz, 1999; Kyong-ae and Lee, 2005; Svolik, 2008). Especially after the so-called "third wave of democratization", as formulated by Samuel Huntington (1991), many new cases and questions regarding democratic consolidation have come up. Democratic consolidation is defined in numerous ways. Some scholars focus on the attitude of subjects; others emphasize the importance of introducing new institutions in order to consolidate democracy. 
Lamounier and De Souza (1993: 295) argue that democratic consolidation "refers to overcoming certain institutional stages in transition from authoritarian rule", up to a point where democracy becomes, in Linz's words, "the only game in town" (1990: 156). According to this description, democratic consolidation is not merely about the introduction of democratic institutions such as elections and political parties, but also about the mindset of actors and the need to reach a consensus. In order for democracy to be "the only game in town", political actors as well as other citizens must accept democracy as the best possible option. Then it becomes likely that this democracy will endure (O’Donnell, 1996:37). When this condition is reached, we can speak of a consolidated regime. The process of democratic consolidation reaches from the moment that the democratic regime emerged after a transition from another regime type, until the democracy becomes "consolidated".

According to Park Kyong-ae and Hang Lee, democratic consolidation is the establishment of democratic rules to build a consensus between political actors. In their study on democratic consolidation in the Republic of Korea, they describe the nature of the process as follows: "When a political regime is in transition from authoritarian to democratic, the democratic rules of the game must be immediately agreed upon among major political actors even if they are yet to be tested in a new political setting. Therefore, a major task in democratic consolidation is to build consensus on democratic rules of the game for resolving conflicts among major political actors and forces" $(2005 ; 48)$.

When a regime becomes consolidated is thoroughly described by Linz and Stepan. They argue that a democratic regime can be consolidated on three levels: 
behaviorally, attitudinally, and constitutionally (1996: 6). A regime is

behaviorally consolidated "when no significant national, social, economic, political, or institutional actors spend significant resources attempting to achieve their objectives by creating a nondemocratic regime or turning to violence or foreign intervention to secede from the state" (1996: 6). In other words, the behavioral definition of democratic consolidation refers to a state where there a no actors seriously trying to secede from the polity. The attitudinal definition beholds that a "regime is consolidated when a strong majority of public opinion holds the belief that democratic procedures and institutions are the most appropriate way to govern collective life in a society such as theirs and when the support for antisystem alternatives is quite small or more or less isolated from the pro-democratic forces" (1996: 6). This level of definition is close to the definition that democracy has to become the only game in town. On the mass level, people have to believe that a democracy is the best possible regime type for the polity. According to Linz and Stepan's constitutional level definition, democratic consolidation is reached "when governmental and nongovernmental forces alike, throughout the territory of the state, become subjected to, and habituated to, the resolution of conflict within the specific laws, procedures, and institutions sanctioned by the new democratic process" (1996: 6). This definition seems intertwined with the idea of a strong rule of law, which is recognized by other authors to be a requirement for democratic consolidation (e.g. Diamond, 1999; Diamond, Linz and Lipset, 1995).

Larry Diamond argued that "[democratic] consolidation is most usefully construed as the process of achieving broad and deep legitimation, such that all significant political actors, at both the elite and mass levels, believe that the 
democratic regime is the most right and appropriate for their society, better than any other realistic alternative they can imagine" (1996: 2). This definition by Diamond is the one that will be used in this study. His definition is more direct than the threefold definition formulated by Linz and Stepan. Meanwhile, it does contain the core feature of the definition where most authors agree upon, being the process towards becoming "the only game in town". Earlier in his career, Diamond described the process of democratic consolidation together with Linz and Lipset as "the struggle to redefine flawed institutions imposed by the authoritarian regime" (Diamond, Linz and Lipset, 1995: 54). This description includes institutions, and numerous other scholars have focused on institutions in the process of democratic consolidation. This study will also focus on the institutions of the past.

\section{$\underline{1.2 \text { History as a Branching Tree }}$}

When focusing on past influences on the process of democratic consolidation, the theories of path dependency and institutional legacies are of great importance. The idea that the institutions of the preceding regime can be of influence on the development of a new regime is central to this thesis. Several definitions have been used to define path dependency. In the overview Theory and Methods in Political Science by David Marsh and Gerry Stoker, Craig Parsons described the "core dictum" of path dependency as to "seek evidence of the pressures, incentives, motivations, and decision-making calculus in any given instance of action [...]. It instructs us to provide 'within-case' evidence of mechanisms that stand independently from cross-case patterns of initial conditions and outcomes" 
(Parsons, 2010: 92). Earlier definitions of path dependency are, for example, the ones of W. Brian Arthur (1994) and Paul David (2000). Their works focused on the economic implications of previous choices and path dependency. David argued that "the core content of the concept of path dependence as a dynamic property refers to the idea of history as an irreversibly branching process" (2000: 8). In a more animated description, Robert Putnam described the impact of path dependence as a journey, stating "where you can get to depends on where you're coming from, and some destinations you simply cannot get from here" (1993, quoted in Ekiert, 2003: 93).

In 2004, Paul Pierson tried to recollect the definitions of Arthur, Paul, and many others, in order to reach consensus on one clear definition of path dependency that is applicable in political science. He describes three characteristics of politics that make the study of path dependency different than in the study of economics: "the absence or weakness of efficiency-enhancing mechanisms of competition and learning, the shorter time horizons of political actors, and the strong status quo bias generally built into political institutions" (2004: 30). To cope with these differences, he advances two different definitions that are applicable in the study of political institutions.

The broad definition he puts forward states that path dependency means "that what happened at an earlier point in time will affect the possible outcomes of a sequence of events occurring at a later point in time" (2004: 21). Pierson argues that this definition doesn't contribute anything more than the mere statement that history is relevant. Therefore, he advocates the use of a more narrow definition, stating that "path dependence has to mean [...] that once a 
country or region has started down a track, the costs of reversal are very high. There will be other choice points, but the entrenchments of certain institutional arrangements obstruct an easy reversal of the initial choice" (2004: 21). This definition contributes more than just the statement that history matters. It indicates that it is possible to reverse choices made in the past, but that it is most likely that the initial choices will prevail since their institutional implications make it difficult to change tracks. Pierson tried to settle on one single definition for path dependency, and he concluded that this definition is the best. Therefore, this definition will be used in this thesis. Pierson gives a metaphor illustrating this process, saying that path dependency is maybe more "a tree, rather than a path. From the same trunk, there are many different branches and smaller branches. Although it is possible to turn around or to clamber from one to the other [...] the branch on which a climber begins is the one she tends to follow" (2004: 21).

\subsection{Institutional Legacies: Constraints and Opportunities}

When path dependency focuses on institutions, it is related to institutional legacies. Numerous scholars have studied the concept of institutional legacies (e.g. Crawford and Lijphart, 1995; Diamond, Linz and Lipset, 1995; Linz and Stepan, 1996; Diamond, 1999; Clare, 2007; Béland and Myles, 2012). The concept of institutional legacies beholds the idea that political institutions generate constraints and opportunities for policy change (Béland and Myles, 2012: S76).

An aspect of institutional legacies is that institutional structures created in the old regime persist in the new regime type (Crawford and Lijphart, 1995: 
172). In the context of regime change this means that the regime type that is being abolished will generate constraints and opportunities for the succeeding democracy. These institutional legacies are present in any regime change, but are most emphatically present after a change in regime type (Clare, 2007: 262). Since this study will focus on a case where the regime type changed, it is plausible that the institutional legacies are clearly present.

In the past two decades, more and more scholars have been focusing on the influence of authoritarian legacies in the process of democratization (e.g. Bunce, 2005; Horowitz, 2003; Pop-Eleches, 2007; Anderson, 1999; Clare, 2007; Crawford and Lijphart, 1995; Markovitz, 1999). Pop-Eleches argues that "historical legacies have to institute the starting point for any systematic analysis of democratization in the post-communist context" (Pop-Eleches, 2007: 909). This fits neatly within the theory of path dependency and institutional legacies.

Institutional legacies are of great importance for political scientists, especially in the field of comparative politics, because they provide many topics and raise interesting questions. "Because the legacies perspective emphasizes the unique historical inheritance [it] suggests the relevance of intraregional comparisons to illustrate how the particular differences in the historical legacies have led to divergent paths" (Crawford and Lijphart, 1995: 173). The emphasis on this unique historical inheritance makes the study of institutional legacies well suited for a case study.

Many scholars found proof in their analysis that institutional choices in the past have determined possibilities for the future. "Historical legacies determine the available alternatives and make some institutional choices more 
likely" (Ekiert, 2003: 93). Linz and Stepan devoted a complete work to the study of transitions from authoritarian regimes towards democracy, and the challenges for these new democracies. Their conclusions are that "the characteristics of the previous nondemocratic regime have profound implications for the paths available and the task countries face" (1996: 55). Their study focuses on Southern Europe, South America and post-communist Europe, and gives good suggestions on which institutional challenges countries face in the time of democratic consolidation. They argue that the challenges new democracies face depend on the kind of authoritarian regime that preceded it (1996: 62).

Diamond, Linz, and Lipset emphasized that "social structures and historical legacies circumscribe and confine the choices available to various political actors at a particular time" (1995: 53). In a later work, Diamond has also addressed the importance of legacies of the past in the process of consolidating democracy. In his conceptualization of democratic consolidation, the legitimacy of the democratic regime is very important (1999: 66). He recognizes that the "legitimacy is shaped by a wide variety of historical and cultural variables" (1999: 78). Certain aspects of the past, and most notably of the past regime, thus have influence on the process of democratic consolidation. Past institutions are a part of these historical variables.

As mentioned before, much of the research in the field of institutional legacies in the process of democratization has been conducted in Central and Eastern Europe (e.g. Barany and Volgyes, 1995; Hanson, 1995; Czaban and Henderson, 1998; Ekiert, 2003; Ekiert and Hanson, 2003; Grzymala-Busse, 2003; Inglot, 2003; Toole, 2003; Pop-Eleches, 2007; Griffiths and Karp, 2008; Malle, 
2009; Olson and Ilonszki 2011; Morrison, Croucher and Cretu, 2012). Social scientists predicted as early as 1992, when the transition of many formerly communist states had just started, that the future of these states would be shaped by its past. "Whatever the results of the current turmoil in Eastern Europe, one thing is clear: the new institutional patterns will be shaped by the 'inheritance' and legacy of forty years of Leninist rule" (Jowitt, 1992, quoted in Ekiert and Hanson, 2003b: 1). Former Soviet states and post-communist democracies have proved to be an interesting subject to study for many scholars. They recognize the legacy of Leninism as an important part in post-communist development in many different facets of society. This perception is effectively caught in a quote from George Schöpflin: "Post-communism [...] deserves its name. Its character is an uneasy mixture of elements of the past and of the different visions of the future that are on offer" (2000: 169). Grzegorz Ekiert dedicated several works to the weight of institutional legacies in the postcommunist region, and he puts forth the argument that "legacies of the communist period had the most important impact on specific paths of reform and types of transformations unfolding across the region during the first decade of postcommunism" (2003: 89). The literature on post-communist democratization and legacies of the communist rule provides a profound overview of the state of the field on the importance of legacies during the process of democratization and democratic consolidation. "It is possible [...] to identify several distinctive features of [institutional legacies] that varied across the region and generated specific sets of opportunities and constraints for political actors" (Ekiert, 2003: 90). 
Scholars have focused on many different aspects of these legacies. Some of them studied very distinct legacies, such as the weapon surplus as a result of the Cold War (Griffiths and Karp, 2008). But most political scientists have devoted themselves to other expressions of the legacies of the past. Tomasz Inglot has examined the role of the extensive social security that the post-communist governments inherited from their socialist predecessors. He argued that it was risky, if not political suicide, for political actors to attempt to change the social security system because of the communist legacy (2003: 225). Therefore, the pre-existing structures of the social policy proved to be pivotal in shaping the post-communist social policy (2003: 240). From his study of the post-communist developments in Poland and Hungary, he concludes that the social policy legacies have helped to stabilize the democracies, because the social security benefits could be used as a "cure" for public discontent. An important side note is that the expensive social security is highly vulnerable to (economic) crises, and that the positive effects may weaken over time (2003: 241-243).

Legacies in the economic and industrial facets of society have also proved to be a topic worth studying. Czaban and Henderson studied the integration of Eastern European economies and firms into the world economy. Their argument is that the situation in Eastern Europe is very complex due to the specific background of the region (1998: 585). The key path dependence they distinguish is that the nature of the communist economy has made the industry prone to monopolies, resulting in low quality products and low production costs. After the transition to democracy, this caused a need for large-scale foreign investments. Czaban and Henderson conclude that all firms are path dependent and are "thus strongly influenced by the particular institutional matrix of the Hungarian 
society and economy" (1998: 607). Silvana Malle evaluated the communist legacies in post-Soviet Russia in the context of the emerging global financial crisis. Her argument is that legacies of the Soviet past disappeared in the 1990s, but slowly started to re-emerge during the global financial crisis. These legacies are both negative and positive (2009: 251-252, 274). Most legacies she distinguishes are not institutional, such as the poor communication with the public and the inconsistent and uncoordinated action of the government. But she identifies the inherited (and institutional) lack of checks and balances in the political arena as a negative legacy that will not "improve the power structure, provide the social cohesion necessary to withstand the effects of the crisis and prevent further disruption" (2009: 274). These studies on post-communist legacies focus on several different facets of the economy and industry. As has become clear, legacies can be discovered in different fields of society.

This paper focuses on institutional legacies in the political arena. Therefore, it is useful to review the literature that is dedicated to the role of legacies in the development of political institutions. Ekiert makes the case that the institutional legacies in the post-communist political arena "account in the most persuasive way for the initial outcomes of post-communist transformation", because "the specific legacies of the communist period and modes of power transfer shaped subsequent political developments and the capacity of various political actors in each country" (2003: 90, 92). According to his analysis, the Central and Eastern European countries with the most successful transition to democracy shared several characteristics in the communist era: [1] the appearance of political conflicts and reforms, [2] a certain extent of marketization and economic liberalization prior to the end of 
communism, [3] a pragmatic political elite and/or substantial political opposition, and [4] a stronger tie to the West (2003: 111). Ekiert argues that these characteristics of the past constitute a legacy that provides the countries in transition with opportunities.

Anna Grzymala-Busse has studied the perseverance of communist parties after the collapse of the Soviet Union, and the influence of the party elites on the transformation of the parties. She derives from her analysis that a more skilled party elite perceived the need for immediate party reforms (2003: 172). At the same time, these elite skills also establish the degree to which the former communist parties centralized or decentralized. Many communist parties had inherited a strongly decentralized structure, with no central administration. In the new situation of party competition and competing for votes on a national level, this was a disadvantage. Therefore, a quick reorganization was needed (2003: 175). Grzymala-Busse concludes her article by stating that the institutions of the past can continue to matter, and that the speed with which the parties adapted to the new rules has been decisive in their success. Political resources, as she phrases it, "had their origin not in the transition [...] but in the decadeslong organizational practices of the communist parties" (2003: 179).

In the same year, James Toole published an article on a very similar topic. He analyzed political parties in eight former communist countries in Central and Eastern Europe. He describes that in many cases, such as Poland, the Czech Republic, and Hungary, the political parties have become very similar to parties in Western Europe. Nevertheless, some differences remain between parties in Western Europe and the East. Toole argues that an important source of these 
differences is the legacy of the communist rule (2003: 101). His findings are similar to those of Grzymala-Busse, in the sense that he also recognizes the importance of the party elites and the elite-needs in the early years of postcommunism (Toole, 2003: 112). Moreover, he distinguished four legacies that influenced the development of political parties in the post-communist era. These legacies are: [1] reluctance of citizens to join political parties, [2] the ability to convert party resources from the communist era into post-communist ones, [3] little funds for party developments, and [4] old-fashioned and expensive intraparty communication-systems (2003: 113). The first two legacies are formulated in the context of the communist party but may be applicable to all single-party authoritarian states, since the characteristics Toole describes are those of authoritarian state-parties and not specifically communist. He explains the first legacy for example by stating that "party membership was often a prerequisite for occupational or educational advantage. As such, it helped co-opt citizens into publicly supporting regimes that were in perennial need of legitimacy" (2003: 113). This explanation is applicable for every single-party authoritarian state, and might therefore be useful in studying single-party legacies in different cases.

In his 2007 article, Grigore Pop-Eleches analyzes legacies and the influence of these legacies on post-communist regime trajectories (2007: 908). He recognizes that no legacy is necessary for post-authoritarian democratization, and thus no legacy is decisive in this process. He argues nevertheless that the "institutional legacies significantly shaped the preferences of political actors and the constraints on their choices" (2007: 909). In his statistical study of legacies and transition outcomes he finds that the outcomes of these transitions were to a 
significant degree shaped by the past (2007: 924). He concludes that the "countries trying to escape their past face an uphill battle in trying to develop well-functioning democratic institutions", and that researchers in the field of post-communist democracies should adopt a more historically grounded realist approach, comprising the realization that some legacies can not be disregarded (2007: 924-925).

A recent article by David Olson and Gabriella Ilonszki is closely related to the topic of this research. Their research focuses on the impact of institutional legacies of the communist era on the legislature in seven post-communist parliaments in Central Europe and the former Soviet Union. They argue that the distinct legacies are sources of divergent paths for the new democracies (2011: 234) The most immediate legacy they distinguish is the communist legislature, with a high organizational complexity. Moreover, the legacy of single-party rule by the Communist Party "meant that there was no inherited parliamentary experience with either rules or structure of how to accommodate the open and organized existence of more than one legitimate political party" (2011: 249). Similar to James Toole's article, these characteristics seem applicable to other single-party authoritarian systems, outside of the former communist territory.

As has become clear in the preceding section, scholars have studied many different aspects of legacies and their impact on post-communist countries. Griffiths and Karp (2008) studied a tangible legacy by focusing on the heritage of a surplus of small arms in Ukraine. But many others have devoted themselves to identifying legacies in the economic and political spheres of post-communist society. Inglot (2003), Czaban and Henderson (1998), and Malle (2009) studied 
the role of authoritarian legacies and identified the legacy of an extensive social security system, industrial monopolies, and a lack of checks and balances as influential in the post-transition period. More related to this study nevertheless, are the articles on the role of institutional legacies in the political arena. The findings of Ekiert (2003), Grzymala-Busse (2003), Toole (2003), Pop-Eleches (2007), and Olson and Ilonski (2007) show that there are numerous ways in which the single-party authoritarian legacy continues to provide opportunities and constraints in new democracies. Grzymala-Busse and Toole studied the influence of the past on the development of political parties, Pop-Eleches argued that the post-communist developments must be seen as a result from their past, and Olson and Ilonszki explain the constraining legacies of the communist legislatures.

\subsection{Leaving Europe and South America}

All of the literature that has been presented in this section has analyzed cases in post-communist Central and Eastern Europe. The reason for this is that much of the research that has been conducted in the field of institutional legacies, and especially legacies of single-party regimes, has focused on this geographical area. This is not surprising. The fall of the Soviet Union and the collapse of many communist single-party regimes have provided political scientists with a variety of interesting cases to study. Because of the common communist past of some Central and Eastern European countries, they lend themselves as exemplary subjects of comparative case studies. 
Nevertheless, there are some limitations of the current literature. The post-communist democracies have proved to be suitable cases to develop and test theories on institutional legacies of single-party regimes, but a bias threats the value of these theories. A substantial portion of the research has been conducted in the same geographical area, and therefore it is plausible that the specific characteristics of communism or other common features of Central and Eastern European culture or history distort the theory-building and make the theory of institutional legacies less universally applicable.

Studies aimed at the legacies of other authoritarian regime types, such as militaristic or personalist regimes have also mainly been conducted in concentrated parts of the world. New democracies in Southern Europe and South America have been the cases of several studies on numerous effects of these legacies (e.g. Linz and Stepan, 1996; Pereira 2001; Costa Pinto, 2006, 2010; Barahona de Brito and Sznajder, 2010; Morlino, 2010; Palacios Cerezales, 2010; Costa, 2011; Groves, 2012). This entails the risk of a second bias: an overrepresentation of European and South American cases in the literature on the role of legacies. To rectify this bias, more studies in other parts of the world such as Africa and Asia need to be conducted.

This study aims to fill this gap in the literature with a case study of institutional legacies of the single-party regime in the democratic consolidation in Taiwan. Countries in Asia have been underexposed in this body of literature, and therefore this case study of an Asian democracy is a valuable contribution. With a transition from a single-party authoritarian regime at the end of the 1980s, the case of Taiwan bears several similarities to the cases in Central and 
Eastern Europe, but it is dissimilar in the sense that it does not have the same history of communist rule and culture. Therefore, this is an appropriate case to circumvent the potential bias.

The findings of this thesis demonstrate that institutional legacies of the authoritarian regime in Taiwan have played a noteworthy role during the process of democratic consolidation on the island, at least in the political society of the ROC. The effects of these legacies were not exclusively positive or negative: they provided both constraints and opportunities for the democratizing of the state. These findings confirm the importance of institutional legacies when assessing the development of new democracies. Nevertheless, more research on institutional legacies is needed in this underrepresented region in the literature. 


\section{Taiwan: from Safe Haven to Democracy}

Because this study aims to assess the role of legacies of the past, it is useful to have an overview of the course of Taiwanese history. This chapter provides a short introduction in the history of Taiwan and the political developments in the ROC during non-democratic rule.

From 1895 until 1945, the island of Taiwan was part of the Japanese empire. After the Japanese defeat in the Second World War, they yielded it to China. On the Chinese Mainland at the time, the Chinese Communist Party (CCP) and the KMT raged in a heavy civil war (Rigger, 1999: 55-56). The KMT lost the Civil War in 1950 and the CCP took control over the Chinese mainland. The KMT retreated to the Taiwanese island. The KMT legitimized its rule over Taiwan by referring to its role in the Chinese Nationalist revolution and its claim to be the ruler of all China (Moody, 1993: 7).

In 1950, Martial Law was installed on the island, and it stayed in place for almost forty years until 1987. The Martial Law prohibited the formation of political parties, gave the government broad powers to imprison dissenters, and imposed state control over the media (Rigger, 1999: 21). During the KMT's authoritarian rule, there have nevertheless been two opposition parties. But these parties were nothing more than puppets to the KMT, and they were dubbed the "flower vase parties". The Martial Law also restricted some constitutional rights such as the freedom of speech and assembly (Fell, 2005: 10). Moreover, the Martial Law prohibited new elections for the Legislative Yuan. The KMT argued that issuing new elections was not possible because the Chinese people on the Mainland were not able to vote. They were afraid to loose their 
legitimacy if they would hold elections on Taiwan and as a consequence exclude the people of Mainland China. Therefore, the representatives in the Legislative Yuan elected in 1947 stayed in office for an indeterminate time (Rigger, 1999: 63).

At the time the KMT retreated to Taiwan, nobody had expected that the KMT would control Taiwan for so long. Probably the only reason for its survival in the early years was the outbreak of the Korean War in the same year. To protect its interests in Southeast Asia, the United Stated sent out their Seventh Fleet to protect the Taiwan Strait. Moreover, the KMT signed a Mutual Defense Treaty with the United States in 1954, which protected the ROC from being taken by the CCP. (Fell, 2005: 9)

In 1987, president Chiang Ching-kuo ended the Martial Law that had controlled the government and the state for almost forty years and announced democratic reforms. By that time, much had changed within the ruling party in those four decades. When the KMT fled to the island in 1950, the members who originated from the Chinese mainland dominated the party. Those people were set on the goal of reuniting the PRC and the ROC under the rule of the KMT. But when the years passed, the number of party members from the mainland declined while the portion of ethnic Taiwanese members increased. The domination of this group from the mainland had eroded (Fell, 2005: 12).

What was the reason for ending the Martial Law and to start working towards a more democratic state? First and foremost, all the democratization that has found place in Taiwan has been initiated by the KMT, which has been the ruling party until that time (Moody, 1992: 7). There are several aspects that have 
ignited this development. First, the United States had pushed Taiwan to democratize. Because the KMT believed that the threat of an invasion from Mainland China had reduced, they could agree with lifting the Martial Law (Dickson, 1996: 65). Secondly, there had been a series of large-scale demonstrations in Taiwan. Big crowds entered the streets to protest, and these repeated signs of dissatisfaction under a large part of the people has influenced the decision of the KMT to loosen the parties grip on the state (Moody, 1992: 89). Thirdly, the political opposition in Taiwan should be credited for the political change. On the local level, some political competition was allowed, and this had led to some opposition movements that challenged the KMT in regional elections. The liberalization needed the opposition to some extent, since the process would have held no significance without an organized opposition (Moody, 1992: 162). Fourthly, other international factors have also played a role in the loosening of the authoritarian rule. Many countries all over the world did not recognize or stopped to recognize the ROC or the position of the KMT as legitimate ruler over both Mainland China and Taiwan. Therefore, it needed to reform in order to keep its legitimacy. Lastly, the development of Taiwan on the industrial and economic level led to increased social and political mobilization, which has led to increased ideological and political competition, also within the ranks of the KMT (Chu and Lin, 1996: 79). The KMT tolerated most of these opposition movements and competition, as long as they kept away from "certain forbidden zones". Examples of these forbidden zones are the questioning of KMT's legitimacy as the ruler over Mainland China, and the virtue of the highest-ranking politicians of the KMT (Moody, 1992: 8) 
Thus, president Chian Ching-kuo initiated the democratic reforms in 1986, with the official ending of the one party system (Tien, 1996: 11). When the president died in 1988, his former Vice President Lee Teng-hui succeeded him. This was a breakthrough, because Lee Teng-hui was not born on the mainland like his predecessors but he was born on Taiwan. The elections of the National Assembly in 1991 finally ended the power of the politicians who got elected in 1947 on Mainland China. Many of them had already passed away or retired, but some were still in office when they were forced to retire and make place for the newly elected officials. The 1991 elections are an important moment in the democratization of Taiwan, since it was the first time that the electorate had the potential to change the ruling party on the national level (Fell, 2005:3).

After the KMT's defeat in the Chinese Civil War, the regime established the ROC on Taiwan. For over forty years, the authoritarian KMT has dominated the government of the ROC without changing the membership of the National Assembly and the Legislative Yuan after 1947. Political opposition was allowed to a certain extent though, and people that were not a member of the KMT could compete in local elections. In 1986, president Chiang Chin-kuo started democratization and in the beginning of the 1990s elections of the National Assembly, Legislative Yuan and provincial governors continued this process.

Within less than a decade after the first open national elections, critics called Taiwan a democracy well under way to become consolidated and an example of successful democratization (e.g. Moody, 2002: 27; Göbel, 2006: 61; Shih, 2007; Shih, Sun and Wang, 2012: 313). It is quite an achievement that the ROC democratized so quickly, considering that many other states that 
democratized during the third wave in the 1970s and 1980s have relapsed into a certain form of authoritarianism or have not managed to develop democracy to the next level (Rose and Shin, 2001; Foweraker and Krznaric, 2002). 


\section{Approaching the Legacies}

This chapter will discuss the research method that is used to answer the research question, and explain why certain data are selected and used to assess the role of institutional legacies in the process of democratic consolidation in Taiwan. There are countless legacies of the past that can be examined in every remote corner of society. This study will focus on one single specific formal institution in the political arena, being the elections and electoral rules. Elections are one of the core institutions of modern day democracies, and therefore a prime institution to focus on in the context of democratic consolidation.

\subsection{Taiwanese Elections: Building Blocks for Theory}

The study will apply the case study method to contribute to the literature on institutional legacies. There is an ongoing debate about the merits and disadvantages of different research methods. Several methodologists in the discipline of political science treat this research method with suspicion (e.g. Achen and Snidal, 1989; Lieberson, 1994, Njolstad, 1990). John Gerring's famous 2004 article nevertheless pointed out the merits of case studies in the social sciences. He countered the argument of the critics by arguing that much of the knowledge, theories, and literature in the social sciences are a result of numerous case studies (2004: 341).

This case study aims to contribute to the literature on institutional legacies in accordance with the "building block theory", formulated by George and Bennett (2004). According to this theory, case studies of subtypes of a phenomenon contribute to a larger body of literature (2004: 76). The "subtypes" 
under investigation in this study are the legacies of elections and electoral rules on the process of democratization. This is a building block of the larger "class" of institutional legacies, and fills a "space" in the theory of these legacies. An analysis of a subclass with a smaller scope is often useful, because they generate more precise knowledge of a smaller part of a theory (2004: 77).

Gerring defines a case study as "an intensive study of a single unit for the purpose of understanding a larger class of (similar) units" (2004: 342). He distinguishes three different types of case studies. The type of case study employed in this thesis is what Gerring calls the "type I" case study. In this type of case study, a single unit is examined over time. The merit of this approach is that the researcher preserves the primary unit of analysis (2004: 343). A case study offers a more in-depth analysis and it gives a better insight in causal mechanisms (2004: 346, 348). "The in-depth analysis of a single unit is useful in elucidating causal mechanisms because its characteristic style of evidencegathering [...] is likely to provide clues into what connects a purported $\mathrm{X}$ to a particular Y" (2004: 349). Furthermore, a case study permits an extensive examination of cases even with relatively limited resources (Collier, 1991: 9).

It is important to be aware of the weaker points of the case study method and the building block theory. Compared to a cross-unit analysis, a case study is less representative and it is hard to generalize the conclusions of a case study and formulate a general conclusion or theory based on a case study (Gerring, 2004: 346). It is difficult to apply the same research to other cases because of the case-specific nature of the research design. As a result of these restrictions, a case study contributes less to theory building than a research design with more 
cases (Collier, 1991: 9). The disadvantage of using the building block theory is that many more studies of different subclasses are needed to formulate a general theory. Many studies on institutional legacies, however, have already been conducted. The studies of the single-party institutional legacies in Central and Eastern Europe can be treated as other small building blocks of the institutional legacy theory. This study, together with these building blocks from case studies in former communist countries, contributes to the formulation of a general theory (George and Bennett, 2004: 78).

Overall, a case study is the appropriate research design to analyze the role of prior legacies in the process of democratic consolidation in Taiwan. This research is an exploratory study, which can contribute to future research. "It is the very fuzziness of case studies that grant them a strong advantage in research at exploratory stages" (Gerring, 2004: 350). The research question focuses on the causal relationship between the institutions of the old and the new regime. The merits of a case study in exploring causal mechanisms surpass the drawbacks of decreased possibilities to generalize the conclusions.

\section{$\underline{3.2 \text { Institutions from Past to Present }}$}

Much of this research is based on academic literature. There are numerous publications on the elections in Taiwan during the process of democratization as well as during the single-party era (e.g. Solinger, 2001; Zhu, Diamond, and Sin, 2001; Roy, 2003; Tsai, 2005; Lin, 2006; Chih, 2007; Simon, 2010; Stockton, 2010). This study aims to detect continuities in the formal institution of political elections in this literature, and assess the role of these legacies in the context of 
democratic consolidation. In addition to this literature, data from election results and the expansion of political parties are used. The benefit of assessing scholarly articles is that they give a broad overview of many components of elections and electoral law. Moreover, they make complex and often not fully translated documents accessible. The downside of this approach is that it brings along the risk of copying a certain bias or subjectivity that the author or the research might have. In order to cope with this weakness, this study includes many articles from different journals and publications. In doing so, the risk of copying a bias or measurement error is reduced.

The goal of this study is to explore how the institutions of the past have influenced the process of democratic consolidation. In order to do this, it is required to establish which institutions are the "old" institutions of the past, and which are new. The political change in Taiwan was initiated in the 1980s, and its implications became profound for the first time in the National Assembly elections of 1991. The announcement of president Chian Ching-kuo to abolish the one party system in 1986 can be seen as the pivotal point (Tien, 1996: 11). From that moment on, the KMT elite slowly but steadily worked towards democracy. Therefore, institutional change that occurred after that year was directly or indirectly aimed at achieving this democratic status and consolidating it. Thus, institutions that were established before 1986 are considered the old institutions. 


\subsection{Taiwan: a Single-Party Legacy in Asia}

This research focuses on elections and electoral rules in Taiwan. The independent variables are the electoral rules in the authoritarian period. The dependent variables are the elections and electoral rules during the process of democratic consolidation after the transition. The selection of this specific subunit of institutional legacies is motivated by the limited scope of the research and the importance of elections. It is not possible to assess all components of institutional legacies, and therefore it is necessary to focus on one or a few institutions. This is in accordance with the building block theory that is set out by George and Bennett, in which each study of a subunit fills a "space" in a more general theory (2004: 78). The choice to focus on elections is driven by the role that elections have in the consolidating democracy. Elections are a core element of modern day democracies, and the way in which citizens perceive the practice and functioning of elections is important for the process of democratic consolidation (Robbins and Tessler, 2012).

When selecting a case, it is important to be aware of the risk of selection bias. There are many different ways in which a bias can arise within social science research. Especially case selection based on the dependent variable is damaging to the value of a study (King, Keohane and Verba, 1994: 129). The case selection in this research is based on the independent variable: electoral institutions in a previous authoritarian regime. King, Keohane and Verba argue that case selection based on the independent variable causes no interference problems, because this selection procedure does not predetermine the outcomes of the study (1994: 137). Electoral institutions in authoritarian regimes are 
commonly associated with single-party states. By selecting the case on this variable, the link with the literature on the institutional legacies of single-party regimes in Central and Eastern Europe is obvious. By choosing a case that also has a single-party legacy, some other variables are held constant. At the same time, this case provides the necessary variation that makes it a contribution to the literature by studying a case in a region that has been underrepresented (George and Bennett, 2004: 83). 


\section{Framework for Analysis}

This aim of this chapter is to explain what variables will be measured to assess the role of institutional legacies. As explained in the previous section on the case selection, both the independent and dependent variables are institutions. Therefore, the concept of institutions must be defined before the analysis. The second section in this chapter will explain Linz and Stepans framework of analyzing developments in the political society arena.

\subsection{What are Institutions?}

It is useful to study institutions in the context of democratic consolidation, since the two concepts are closely related. As Petr Kopecký pointed out: "if consolidation of democracy as a process is all about routinizing formal rules into actual patterns of behavior, then institutionalization is $[. .$.$] a concept almost$ synonymous to it" (2001: 10). In the past decades, many scholars have tried to analyze developments in political science by focusing on institutions. There are numerous definitions of institutions and different approaches to study these institutions (e.g. Meyer and Rowan, 1977; March and Olsen, 1984; Searing, 1991; Calvert, 1995; Hall and Taylor, 1996; Miller and Banaszak-Holl, 2005). A commonly used definition of institutions is formulated by James March and Johan Olsen (2006). Their definition is widely accepted by political scientists, and has been used in The Oxford Handbook of Political Institutions (Rhodes, Binder and Rockman, 2006). According to March and Olsen, "an institution is a relatively enduring collection of rules and organized practices, embedded in structures of meaning and resources that are relatively invariant in the face of turnover of 
individuals and relatively resilient to the idiosyncratic preferences and expectations of individuals and changing external circumstances" (2006: 3).

An alternative to this description is a definition that includes the possible sanctions when one does not obey to the rules. Svezotar Pejovich, for example, emphasizes the "sanctions such as fines, imprisonment, and execution" in his definition of institutions (1998: 4-5). This study will stick to March and Olsens definition, since this study focuses on formal institutions embedded in the law, and electoral rules are a fine example of those.

Several scholars also started to address the so-called informal institutions: informal, non-written rules that influence the formal institutions (e.g. O’Donnell, 1996; Böröcz, 2000; Helmke and Levitsky, 2006; Grzymala-Busse, 2010). In 2006, Gretchen Helke and Steven Levitsky edited an overview on the influence of these informal institutions. They define informal institutions as "socially shared rules, usually unwritten, that are created communicated, and enforced outside officially sanctioned channels" (2006: 5). This definition distinguishes the informal institutions from the formal ones. Grzymala-Busse lively described the informal institutions as the "graffiti' counterpart to formal, or 'parchment' institutions" (2010: 312). Informal and formal institutions are similar to each other in the sense that they both comprise of rules and certain sanctions when these rules are disregarded (Helmke and Levitsky, 2006: 5; Grzymala-Busse, 2010: 313). It is important to keep in mind that informal institutions are not a residual category catching all the other factors that shape behavior. Helmke and Levitsky argue that the informal institutions should be 
narrowly defined as shared expectations, in contrast with the broader shared values that form culture (2006: 6-7).

This study focuses on formal institutions, because they are better suited for objective analysis. The risk of measurement errors is low when the subjects of analysis are formal institutions such as elections and electoral rules. Nevertheless, the analysis will touch upon some informal legacies of the elections under authoritarian rule, because they have had an influence on the development of the democratic consolidation.

\subsection{Legacies in Five Arenas}

Linz and Stepan's study (1996) is very important to this paper, since they have been pioneers in connecting legacies from the past to the processes of democratic transition and democratic consolidation. They describe these legacies as the profound implications the characteristics of the previous nondemocratic regime have "for the transition paths available and the tasks different countries face when they begin their struggles to develop consolidated democracies" (1996: 55). They have provided scholars and students with a framework that makes it possible to study the required adjustment of old institutions of the authoritarian regime to suit the process of democratic consolidation.

To study this matter, Linz and Stepan have distinguished five "arenas" that need to be improved in order to reach democratic consolidation after regime change. These arenas are [1] rule of law and civil society, [2] political society, [3] constitutionalism, [4] state apparatus, and [5] economic society (1996: 14). 
Legacies in these arenas are thus worth to be examined to reveal the role of institutional legacies in the process of democratic consolidation. In the arena of the civil society they focus on civil liberties. They measure the political society arena by looking at the conditions of the elections and the ability of citizens to form parties. The arena of constitutionalism is studied based on amendments to the constitution, or the adoption of a new one. The fourth arena, the state apparatus, can be examined by looking at the appearance of purges in the bureaucracy. Regarding the economic society, they argue one must focus on the privatization of property and the amount of social regulation for the market (1996: 62-64). Many of the topics they suggest in the five arenas are institutional developments that aim to terminate authoritarian practices and to create the faith that democracy is the best possible option for the society.

Alternative frameworks for analysis are proposed by for instance Andreas Schedler (2001) and Larry Diamond (1999). Schedler has published a paper on the different approaches for political science research related to institutions in the process of democratic consolidation. He distinguishes three levels of measurement: [1] behavioral foundations, [2] attitudinal foundations, and [3] structural foundations (2001: 69). On the level of structural foundations of democracy he focuses on "socioeconomic factors as well as those who stress institutional factors". He proposes data on per capita income and analysis of the election process as a manner to study these institutional developments (2001: 80-81).

Schedler's theory is a reasonable alternative to see how scholars have measured topics related to democratic consolidation. Nevertheless, there are 
other approaches that might be useful. Diamond has a different focus when studying aspects relevant to democratic consolidation. Instead of five arenas or three foundations, he concentrates on three fields: [1] democratic deepening, [2] political institutionalization, and [3] regime performance (1999: 74). Progression in these three fields leads to more public commitment to the democratic cause. In turn this leads to increased legitimacy of the democratic regime (1999: 192). The commitment to the democratic cause and the legitimacy of the regime type is the essence of democratic consolidation in Diamonds work, since he defines democratic consolidation "as the process of achieving broad and deep legitimation", as discussed before (1996: 2). Institutions and institutional developments should therefore contribute to the legitimacy of the democratic regime, in order to consolidate democracy.

The works of Linz and Stepan, Diamond, and Schedler all offer quite different perspectives on what to measure and what to focus on when studying the process of democratic consolidation and the institutions relevant for this process. There is some overlap in their approaches though. All three authors argue that the attitudes on the mass level regarding the regime type are crucial to democratic consolidation. Schedler formulates this attitude as merely one of three categories to study, while in the works of Diamond and Linz and Stepan, all arenas or tasks are in some way oriented toward reaching this attitude. Diamonds three tasks are all aimed at achieving the positive attitude toward democracy. Linz and Stepan's arenas overlap with, or contribute to, the tasks of "political institutionalization" and "regime performance" as proposed by Diamond, and thus indirectly contribute to the attitude towards democracy. 
In this research, the approach used by Linz and Stepan is guiding. Their extensive study of the post-authoritarian development of new democracies in Eastern Europe, Southern Europe, and South America has resulted in a framework to study topics that are related to the process of abolishing authoritarianism and achieving democratic consolidation. The research of Linz and Stepan aspired to expose problems that states face during the period of democratic transition and consolidation, and the continuing appearance of their work in current studies indicates its merit. The approach of Linz and Stepan is most detailed and provides relatively clear factors that must be measured, while Diamond and especially Schedler work on a more abstract level and do not give clear examples of what institutions to focus on.

According to Linz and Stepan, the amount of work that needs to be done in the arenas depends on the preceding regime type, because the character of the preceding authoritarian determines the situation in the five arenas when the new democratic regime takes over (1996: 62-64). Therefore, the old regime burdens the new democracy with different constraints and opportunities. In the arena of constitutionalism, for example, a democratic regime succeeding a posttotalitarian regime faces different challenges than a democratic regime that has been preceded by a sultanistic regime. The post-totalitarian legacy leaves a fictive constitution, which needs to be democratized and improved. A sultanistic regime, on the other hand, often does not have a constitution at all. And even when it does, it normally gets violated so severely that this constitution needs to be abolished completely and a new constitution needs to be drawn up. This 
leaves the new democratic regime with different tasks than when a constitution "merely" needs to be amended (1996: 63).

Thus, it is necessary to classify the non-democratic regime that ruled Taiwan for more than four decades. There are various frameworks that can be used to define regime types (e.g. Linz and Stepan, 1996; Geddes, 1999; Gandhi, 2008). It is nevertheless most relevant to classify the ROC following the categorization of Linz and Stepan, since their approach of institutional legacies in the process of democratic consolidation is important to this research. Their approach is obviously also based on their own categorization.

Linz and Stepan distinguished four non-democratic regimes: totalitarianism, post-totalitarianism, sultanism, and authoritarianism (1996: 40). They used this categorization for their argument that the paths of new democracies are partly determined by the nature of the preceding regime. Linz and Stepan describe totalitarianism as an ideal type, which has "eliminated almost all pre-existing political, economic, and social pluralism, has a unified, articulated, guiding, utopian ideology, has intensive and extensive mobilization, and has a leadership that rules, often charismatically, with undefined limits and great unpredictability and vulnerability for elites and nonelites alike" (1996: 40). Post-totalitarianism can have some constraints on the leader, it can have some critics of the regime in the civil society, or it possibly has developed forms of institutional and social pluralism (1996: 42). Sultanism is defined as a regime type where "the private and the public are fused, there is a strong tendency toward familial power and dynastic succession, there is no distinction between a state career and personal service to the ruler, there is a lack of rationalized 
impersonal ideology, economic success depends on a personal relationship to the ruler, and, most of all, the ruler acts only according to his own unchecked discretion, with no larger, impersonal goals" (1996: 52). Authoritarianism is a regime type where one leader or an elite group exercises power, with extensive effort to co-opt elite groups in leading positions. These elite groups have legitimacy and power on their own. Secondly, authoritarian regimes do not have highly articulated ideologies regarding the role of the leading party. Lastly, in authoritarian regimes there is no mass mobilization of the population, in contrast to the (post-) totalitarian regimes (1996: 46-49)

The ROC must be categorized as an authoritarian regime. This categorization is based on the characteristics of the ROC mentioned in the second chapter and will become more clear during the description of the electoral institutions in the authoritarian era in the ROC in the next chapter. The presence of local elections and a certain level of plurality during the non-democratic period exclude the possibility to categorize the ROC before the democratic transition as a totalitarian or post-totalitarian country. The sultanist regime type is also not applicable in this case. Even though the ROC has known some strong leaders with Chiang Kai-shek and Chiang King-kuo, the private and public spheres never fused (Moody, 1992). Moreover, the KMT has tried to co-opt elite groups from the very beginning of their rule, which is an attribute of authoritarianism.

Now the former non-democratic rule over Taiwan has been defined as authoritarian, it is possible to determine the challenges the country faces in the arena of political society in their effort to consolidate democracy. According to 
Linz and Stepans framework, a new democracy coming from authoritarian rule needs to create conditions that ensure free and fair electoral competition between parties. Therefore, "the formation of parties needs to be legalized and restrictions on specific parties lifted". Besides this, it is sometimes necessary to re-establish the rights of some political actors or to dismantle the former state party (1996: 62). The second arena is indicated by the development of political parties, elections, electoral rules, as well as interparty alliances and legislatures. All conflicts in the arena of politics must be solved in a democratic fashion (1996: $8,10)$. The next chapter will analyze the electoral institutions in place before and after the transition to democracy, and assess their role in the process of democratic consolidation. 


\section{Institutional Legacies in the ROC}

As has been addressed shortly in the second chapter, the ROC has a long history of elections under authoritarian rule. Local offices as well as a limited number of seats on the Legislative Yuan were open for elections during the era of authoritarian rule in Taiwan (Chao and Dickson, 2002: 7). This chapter first defines the electoral rules that were established and used in the elections under authoritarian rule. In the second section, the continuities of these electoral rules after the regime change are presented. The third section on the other hand sets out how the democratizing regime has tried to cast off these continuities. The final section assesses the implications of the continuities in electoral rules after the transition to democracy had been initiated.

\subsection{Electoral Institutions under Authoritarian Rule}

In order to analyze the developments of electoral rules in the process of democratic consolidation, it is necessary to thoroughly understand the electoral rules in the single-party era. The local elections under authoritarian rule were held almost without interruption since the 1950s (Tien, 1996: 4). The competition for these elections was mostly between members and factions within the KMT, but it was also possible for non-members to compete in these local competitions. Regularly, non-KMT candidates were serious competition for the KMT members in districts all over the island. As the years went by, the opposition got better organized and the challenging of KMT members in local elections persisted all the way from the 1950s to the actual democratization at the end of the 1980s (Tien, 1996: 5). 
The first electoral processes on Taiwan were instituted in 1935 during the Japanese colonial rule. The Japanese needed the support of the local elites and therefore they let them compete in elections for positions in local assemblies. The goal of these elections was to "draw local elites into a political apparatus controlled by the colonial authorities [...] and make them dependent on the higher-ups" (Rigger, 1999: 36). When the colonial rulers established these elections, they mimicked the electoral system that was being used in Japan at the time. This system was the uncommon "single non-transferrable vote system" (SNTV) in multi-member districts (MMD) (Rigger, 1999: 36).

When the KMT gained control over the island after the Second World War, this electoral system remained intact. The local elections helped the KMT to strengthen its control over the island in several ways. First and foremost, the local elections legitimized the rule of the KMT over the island. But secondly, the local elections helped to nurture relationships between the KMT and the local elites (Lin, 2006: 123-124). The KMT used the elections on the local level to find the best grassroots leaders. These leaders had to be able to successfully mobilize voters and win their support. Once these grassroots leaders had been identified, the KMT co-opted them in the party (Rigger: 1999: 21-22). Moreover, the elections helped the KMT to maintain the appearance of democracy in Taiwan, in a sharp contrast to their communist rivals on the Chinese Mainland (Solinger, 2001: 32).

In MMD elections, people vote for candidates who run for multiple seats in the local assembly. The SNTV system beholds that each elector could cast one vote. When a candidate has received enough votes to obtain one of the vacant 
seats, the remainder of the votes cast on this candidate cannot be transferred to another candidate of the same party or faction (Rigger, 1999: 36). As a result, candidates from the same party did not only compete against independent candidates, they also competed against each other (Rigger, 1999: 22). The SNTV system was also used for the national elections once certain seats opened up for elections, and remained in place when the transition to democracy had started. The leaders of the KMT believed that the SNTV system would help them to stay in power after the transition and that it would help them to control the process of liberalization (Rigger, 1999:19). Initially, the SNTV system allowed the KMT to maintain a certain advantage over the opposition parties. But soon the opposition and especially the DPP became more organized and the benefits of the SNTV system for the KMT eroded quickly (Rich, 2012: 324).

\subsection{Institutional Continuity after the Transition}

When Lee Teng-hui took office in 1988, the process of democratization speeded up and he initiated constitutional reforms that changed the structure of the government system and the electoral rules (Fell, 2005: 12). The first amendment to the constitution was ratified in 1991 and this amendment established regular elections for the Legislative Yuan and the National Assembly (Mattlin, 2011: 255). Later that year, the first full elections for the National Assembly took place, and the election of new members of the Legislative Yuan followed one year later. The second amendment was ratified in 1992. This introduced the popular election of the president, vice-president, provincial governors and municipal mayors (Mattlin, 2011: 255). By 1993, important institutions for a democratic 
polity, such as political parties and competitive elections, had been successfully established and developed (Tien, 1996: 3). The role of the Legislative Yuan also changed after these reforms. While this body was nothing more than a "rubber stamp" under authoritarian rule, it became an actual law-making body in the 1990s (Tien, 1996: 21).

The number of representatives each district could delegate depended on the size of the population in the district. The district of the capital Taipei for example could delegate seventeen candidates for the Legislative Yuan, but some of the smallest districts could only send one. On average, the districts could delegate 4.5 candidates for the legislative Yuan, and the average number of competitors for these seats was 11.6 (Rigger, 1999: 39). This means that there was heavy competition for the seats. On the other hand, because there were multiple seats available, a small part of the vote was enough to win the elections. In the more populous districts, capturing as low as five to ten per cent of the votes was enough to get a seat (Rich, 2012: 23, 27).

\subsection{Casting off the Legacy}

Parliamentary elections in the ROC were based on the SNTV system until the seventh amendment of the constitution in 2005. It was not an odd move for a modern democracy to abolish this electoral system, because at that time SNTV was only used in Afghanistan, Jordan, the Pitcairn Islands and Vanuatu (Lin, 2006: 118; Rich, 2012: 324). The revision of the constitution in 2005 was prompted by public discontent with the inefficient and chaotic nature of the national legislature. The people of Taiwan hoped that a change in the electoral 
rules and the downsizing of the Legislative Yuan would help to improve the legislature and battle corruption (Lin, 2006: 120; Rich, 2012: 324).

The 2005 seventh amendment to the constitution changed the electoral process in several ways. First, it extended the term of the Legislative Yuan from three to four years (Lin, 2006: 128). Secondly, it cut the legislature in half, reducing the size of the Legislative Yuan from 225 to 113 seats. Thirdly, the seventh amendment stated that the SNTV system was to be replaced by singlemember districts (SMD) (Mattlin, 2011: 257). In the SMD system, people can cast two votes: one for a candidate from the district and one for a party. The winners of the district votes fill 73 of the 113 seats in the Legislative Yuan. 34 seats are allocated through the party lists, and the remaining six are reserved for native aboriginal candidates (Mattlin, 2011: 150). Because there is only one winner for each district in SMD elections, voters tend to vote strategically. This is different in a SNTV system, where multiple candidates can win and strategic voting is thus less likely (Rich, 2012: 324). Moreover, strategic voting tends to favor large parties over small parties, making it harder for minor parties to capture seats. Therefore, the SMD leads to a large group of underrepresented minorities and another group of overrepresented pluralities (Stockton: 2010: 26).

\subsection{Implications of the Legacy}

The electoral rules of the authoritarian past have clearly continued after the transition to democracy in Taiwan. The SNTV system has been used until the seventh amendment of 2005. The preservation of this electoral system has had 
several implications for the development of the political society in democratic Taiwan. This section will explain these implications.

As mentioned before, there have been elections from the very beginning of the ROC on Taiwan. These local elections gave the KMT legitimacy and provided an argument to present itself as 'Free China' as opposed to Mainland China. Nevertheless, these local elections were not very democratic, since official parties were forbidden (Fell, 2005: 10). Besides the local elections, the KMT started to open up a very limited number of seats for elections in the national parliament, starting in 1969. Gradually, more seats in the national parliament opened up, but at a very slow pace. By 1989 , only 30 per cent of the seats were contested (Fell, 2005: 11).

These elections were not democratic, but they have had an important influence on the development of the political society in Taiwan. The reason for this is that they were highly competitive. Competitors in these elections did not run against candidates from other formal parties, but against independents and rival factions within the KMT (Fell, 2005: 10). Moreover, the local elections and the limited elections for seats on the national level forced the KMT to put forth candidates who were popular with the local population and the local elites, in order to win the vote and become elected. Due to this process, the rule of the KMT became more and more dependent on ambitious talented local politicians. Therefore, the power shifted slowly from the center of the party towards the local officials. This development has had two results. On the one hand, it increased competition and tension within the KMT, and on the other side it provided politicians with the valuable experience of competing in open elections 
(Moody, 1992: 119). The increased competition in the KMT and the experience of competing in open elections made way for a modern model of party politics where conflict resolution takes place in a democratic setting. Or another way to put it: "Undoubtedly, the breakdown of KMT authoritarian rule has contributed to the democratization of the KMT itself" (Huang, 1996: 127).

The institutional legacy of the SNTV system has had several implications. An important result of the SNTV system was the generation of factionalism and divisions within the KMT. This had been the case during the authoritarian era, but its implications became clearer after the democratic transition. SNTV tends to cause internal disputes, because members of the same party or faction compete against each other in the elections. These disputes did not only arise in the KMT, but also caused fragmentation in the DPP and other opposition parties during the 1990s (Lin, 2006: 119-120). Even though the KMT tried to maintain the peace within the party by spending a lot of resources on the allocation of votes, this internal competition eventually led to some splits within the KMT. In 1993, for example, a predominantly mainlander faction of the KMT separated itself from the party. This faction eventually established a new political party, the New Party (NP), to compete in elections (Solinger, 2001: 38).

A negative implication of the SNTV system was its high vulnerability for corruption. Scholars have criticized the self-interest of political competitors, their lack of desire to establish a representative government and the degree to which the elections in the SNTV system represent patron-client relationships (Rigger, 1999: 19). This did not change after the transition. Corruption remained a big problem, even though Taiwan had officially become a democracy. The local 
elections under authoritarian rule had facilitated strong patron-client relationships and personal ties were more important than issue-based politics. After the change to democracy, Taiwan still lacked the legal framework to battle this undemocratic characteristic of society. Corruption persevered because there were no rules limiting large scale "loans" and "donations" to legislators (Göbel, 2006: 72-73). The scale of the corruption increased tremendously after the Legislative Yuan became popularly elected. While the local elections experienced only local corruption, the nationwide elections attracted more serious corruption with higher stakes (Moody, 2002: 35). The perseverance of corruption after the transition made the deepening and consolidation of democracy extremely difficult (Göbel. 2006: 77).

The SNTV system is highly challenging for party strategists. Because the surplus of votes a candidate receives can not be transferred to a fellow party member, it is of the utmost importance to predict the outcome and make sure that voters of a party do not all vote for the same candidate. This is a difficult challenge, because the individual candidates of the same party normally appeal to the same group of voters because they have a similar program (Rigger: 1999:40). Therefore, elections in a SNTV system are less based on issues than other electoral systems. The competition is more about the candidates' charisma, and there are many ways for candidates to manifest themselves other than through taking a position in political issues. This attribute of SNTV elections is illustrated by a survey of voters in the Taipei City district after the 1989 local elections. This survey points out that "68 percent of the respondents who preferred the DPP's position on direct presidential elections and 69 percent of 
those who agreed with the DPP on the independence issue nonetheless reported voting for KMT candidates" (Rigger, 1999: 43).

The SNTV system poses several challenges to new parties. First, these parties need to create a strong grassroots voter base, whose votes they could allocate to their candidates. Secondly, the party needed to learn how to estimate the number of votes for each separate candidate and how to allocate these votes. Thirdly, new parties needed to set a clear program, to prevent candidates from undercutting one another during the elections (Rigger, 1999: 123). The New Party (NP) allocated its votes very efficiently during the 1995 legislative elections, thanks to their motivated and high-educated supporters. The NP allocated votes to their candidates by assigning voters to candidates on the basis of their birth dates. They managed to capture 13 per cent of the seats (see table 5.1).

Table 5.1: Legislative Yuan Elections with SNTV

\begin{tabular}{|l|r|r|l|r|r|}
\hline & $\mathbf{1 9 9 2}$ & $\mathbf{1 9 9 5}$ & \multicolumn{1}{|c|}{$\mathbf{1 9 9 8}$} & \multicolumn{1}{|c|}{$\mathbf{2 0 0 1}$} & $\mathbf{2 0 0 4}$ \\
\hline KMT & $53.0(59.6)$ & $46.1(51.8)$ & $46.4(54.7)$ & $28.6(30.2)$ & $32.8(35.1)$ \\
\hline DPP & $31.0(31.1)$ & $33.2(32.9)$ & $29.6(31.1)$ & $33.4(38.7)$ & $35.7(39.6)$ \\
\hline NP & & $13.0(12.8)$ & $7.1(4.9)$ & $2.9(0.4)$ & $0.1(0.4)$ \\
\hline PFP & & & & $18.6(20.4)$ & $13.9(15.1)$ \\
\hline TSU & & & & $8.5(5.8)$ & $7.8(5.3)$ \\
\hline
\end{tabular}

Note 1: The first percentage is the parties' vote shares. The party seat shares are shown in parenthesis.

Note 2: This table only shows parties who gained at least five percent of the vote in one election. Minor parties, independents, and aborigines are responsible for the remaining votes.

Source: Dafydd Fell (2006: 23).

Some of the implications of the SNTV system described above may give the impression that this system does not facilitate successful democracy. There are nevertheless some aspects of this electoral system that help the development of democracy. The SNTV system is penetrable for new parties. The successful 
emerging of the NP in the 1995 elections, winning 12,6 percent of the seats, is a prime example. The successful entrance of the People First Party (PFP) and the Taiwan Solidarity Union (TSU) in 2001, with respectively 20,4 and 5,8 percent of the seats, strengthens this claim (see table 5.1).

The SNTV does facilitate greater proportionality (Rigger, 1999: 44). Normally, there is a fair degree of proportionality between each party's vote share and seat share in a SNTV system (Hsieh, 2002: 113). In districts with a high population and thus a large numbers of delegates, this means that small parties or independents have a fair chance to win a seat. A study of the 2004 elections has shown that the results of these elections were "perfectly proportional" (Stockton: 2010: 36; see also table 5.1).

The proportionality of the SNTV system also becomes evident when the results of the 2008 elections are examined. These are the first elections of the Legislative Yuan after the ratification of the seventh amendment, and thus the abolishment of the SNTV system in favor of the SMD. In these elections, the KMT received 55,9 percent of the votes but won 75,2 percent of the seats in parliament. The DPP on the other hand got 23,9 percent of the seats while receiving 40,7 percent of the votes (Rich, 2012: 318). This result is highly disproportional, and the DPP would have won a more proportional amount of seats under the SNTV system (Stockton: 2010: 39). Moreover, these electoral reforms have resulted in the near disappearance of third parties in Taiwanese politics. After the 2008 elections, Taiwan started to move from a fairly proportional democracy towards a heavily majoritarian system (Stockton, 2010: $22,36)$. 
As has become clear, the electoral system has had an impact on the development of the political society in Taiwan. The SNTV system that was installed under Japanese colonial rule on the island has been upheld during the authoritarian rule of the KMT. When the regime changed and the transition to democracy was initiated, the SNTV system was preserved. This unusual electoral system has influenced the Taiwanese democracy in several ways. First, its highly competitive character provided politicians from all origins and parties with experience in electoral competition. Secondly, it created factionalism and splits within the parties. Thirdly, the long history of local elections and strong patronclient relationships that are almost inherent to SNTV has led to widespread corruption. Lastly, the SNTV system has posed challenges as well as opportunities for new parties. It is hard to learn how to allocate votes correctly in order to maximize your seat share. On the other hand, the SNTV system is highly proportional and several parties have demonstrated that it is possible to win a significant amount of seats in the parliament.

The seventh amendment of 2005 and the subsequent 2008 Legislative Yuan elections have shown that the SNTV has some elements that encourage political plurality and party competition. The developments from SNTV towards SMD elections appear to be a change from a proportional system towards a heavily majoritarian system, which leads to many unrepresented minorities. The future will show if these developments will contribute to the democratic cause. 


\section{Conclusion}

The aim of this study has been to answer the question what was the role of prior institutions in Taiwan's process of democratic consolidation. In order to provide an answer, this paper has engaged the extensive body of literature on the role of institutional legacies. As has become clear, the majority of the research on institutional legacies, and especially the legacies of single-party authoritarian regimes, has been conducted in certain fixed parts of the world, such as postcommunist Eastern and Central Europe, Southern Europe and South America. To contribute to this literature, this study has focused on a democratizing country in Asia: Taiwan.

The literature has shown that there are several approaches to study institutions in the context of democratic consolidation. The framework formulated by Linz and Stepan plays an important role in this study (1996). They distinguished five arenas where institutional development is needed to develop and consolidate democracy. This study has exclusively focused on one of these arenas: the political society. Focusing on merely one arena provides the opportunity to get a thorough understanding of one subunit. On the other hand, it does limit the possibility to generalize the conclusions, because there are institutional legacies in four other arenas that might have played a significant role. By applying the case study, this research aims to assess one single unit intensively with the purpose of understanding a larger class of similar units (Gerring: 2004: 342). This is in accordance with the building block theory formulated by George and Bennett (2004). The downside of this approach is that the nature of the research is very case-specific. Therefore, it is even more difficult 
to formulate general conclusions. But in combination with other studies, building block case studies are very useful in generating knowledge.

The final chapter of this thesis has been devoted to the analysis of electoral rules in the ROC from the authoritarian era into the process of democratic consolidation. The electoral rules that were used for nationwide elections after the transition to democracy have been a clear legacy of the past. The SNTV system that had been used for the limited elections during the singleparty era was fairly rare at the time of democratic transition in Taiwan. But because the KMT hoped that the SNTV system would help them to stay in power and have control over the liberalization process, they decided to keep using this election system after democratization. The implications of this legacy have been presented in the final section of chapter five.

The first of these implications is the experience with elections. This has led to increased competition within parties, and the need to put forth candidates that are popular with the local electorate. Therefore, the party became more dependent on local politicians and these talented politicians got more influence. The second implication was the increased factionalism and divisions within parties, especially the KMT, as a result of the SNTV system. In SNTV elections, candidates from the same parties compete against each other, which leads to divisions and at times even splits within political parties. A third result of the specific electoral rules that the Taiwanese democracy inherited from the authoritarian past is the widespread corruption. Strong patron-client relationships and vote buying characterize the SNTV system. The corruption became institutionalized under authoritarian rule, when the KMT spent a lot of 
resources to co-opt the local grassroots leaders. When the scope of the elections enlarged after the democratic transition, the scale of corruption increased as well. A fourth effect of maintaining the SNTV system was that it was difficult for parties to gain a significant amount of seats in the parliament. Political parties need to accurately estimate the division of votes between candidates, in order to allocate votes and effectively turn popular support into seats. The KMT had a lot of experience with this process, and thus had an advantage over the opposition. This advantage nevertheless quickly eroded. The fifth and last implication of the institutional legacy is the great proportionality that comes with the SNTV. Small parties or independents did have a fair chance to capture a seat, because the percentage of votes that was needed in some multimember districts was as low as five to ten percent. This led to almost perfect proportionality in the 2004 elections.

Earlier in this paper, democratic consolidation has been defined as "the process of achieving broad and deep legitimation, such that all significant political actors, at both the elite and mass levels, believe that the democratic regime is the most right and appropriate for their society, better than any other realistic alternative they can imagine" (Diamond, 1996: 2). Evaluating the implications of the institutional legacies in relation to this definition of democratic consolidation will help to answer the research question what was the role of prior institutions in Taiwan's process of democratic consolidation.

There are several ways in which the institutional legacies provided opportunities for the ROC to consolidate democracy. The competitiveness of the elections prompted talented politicians to rise and to gain power at the expense 
of the central party administration. People voting for these successful candidates could see that their vote had value as their candidate gained more influence, which enhances their faith in the democratic system. A second way in which the inherited electoral system provided opportunities for democratic consolidation was the result of the increased factionalism and divisions within political parties, especially the KMT. This eventually caused factions to split with the party and start a political movement of their own. This increased the number of political "tastes" the electorate could vote for, which in turn leads to more satisfaction of the electorate with their range of choice. The high proportionality as a result of the SNTV system is the third implication of the legacy that provides opportunities for democratic consolidation. The high degree of proportionality means that the division of seats in parliament is a good reflection of society. This representative composition of the Legislative Yuan seems fair and contributes to the conviction that democracy is most right and appropriate. As noted before, this important aspect of the legacy ended in 2005 with the seventh amendment. Thereafter, the parliament became less proportional and more majoritarian.

Nevertheless, the impact of the authoritarian legacy in the political society also imposed some constraints on Taiwan in its process toward democratic consolidation. The first and foremost constraining legacy was the corrupt nature of the SNTV elections. Corruption was widespread during the local elections under single-party rule, and this informal aspect of the electoral institutions survived the democratic transition. It damaged the belief that a democratic model was the most right and appropriate for the Taiwanese society. Moreover, the strong patron-client relationship and the far-flung vote buying practices 
negatively affected the legitimacy of the parliament. The second negative effect of the SNTV system was the challenge it posed to new political parties. Established, well-organized parties with experience had an advantage because successfully acquiring an amount of seats in SNTV elections requires vote allocation. In order to successfully allocate votes, a party needs to be able to accurately predict the division of votes amongst candidates. When it is hard for new parties to get seats, the image of an impenetrable parliament emerges. This also damages the faith in democracy. This constraint nevertheless eroded in the course of the 1990s when more and more political movements learned how to allocate votes successfully.

As has become clear, there is no unambiguous answer to the question what was the role of prior institutions in Taiwan's process of democratic consolidation. On the one hand, several implications of the legacy the SNTV system have provided opportunities for the consolidation of democracy. On the other hand, some of the effects of the legacies have damaged the legitimacy of the regime and the faith in democracy. Nevertheless, the opportunities do outweigh the constraints for democratic consolidation when only the purely institutional factors are taken into account. The most important legacy that constrains the democratic consolidation is institutionalized corruption. Clientelism is seen as an informal institution (Hite and Cesarini, 2004: 5), since this practice does not have written down rules while it does involve shared expectations and the informal sanction of potential loss of political prestige and success. When this informal institution is disregarded, the opportunities outshine the constraints.

It is thus possible to conclude that the institutional legacies in the political society arena have provided the ROC with a jumpstart in the process of 
democratic consolidation. It is important to emphasize that this conclusion is based on a study of the political society arena. This is a building block in the process of discovering the role of institutional legacies in the democratization of Taiwan. Research within the other arenas of society is needed to provide a more complete assessment of the role of prior institutions in the process of democratic consolidation in Taiwan and other Asian countries.

It is nevertheless ascertained that the theory of institutional legacies that has mainly focused on cases in Central and Eastern Europe, Southern Europe, and South America, is also relevant in a different region of the world. Hopefully the future will show if institutional legacies can have a decisive influence in the consolidation of democracy. This is not identifiable in the political society of Taiwan, since it seems like the government of the ROC successfully casted off some of the legacies that provided opportunities in the process of democratic consolidation. 


\section{Bibliography}

Achen, Christopher H. and Duncan Snidal (1989). Rational Deterrence Theory and Comparative Case Studies. World Politics 41, 143-169.

Anderson, Lisa (ed.) (1999). Transitions to Democracy. New York: Columbia University Press.

Angell, Alan and Benny Pollack (1993). The Legacy of Dictatorship: Political, Economic, and Social Change in Pinochet's Chile. Liverpool: University of Liverpool.

Barahona de Brito, Alexandra, and Mario Sznajder (2010). The Politics of the Past: the Southern Cone and Southern Europe in Comparative Perspective. South European Society and Politics 15(3), 487-505.

Barany, Zoltan and Ivan Volgyes (Eds.) (1995). The Legacies of Communism in Eastern Europe. Baltimore: John Hopkins University Press.

Baviskar, S. and M.F.T. Malone (2004). What Democracy means to Citizens - and why it matters. Revista Europea de Estudios Latinamericanos y del Caribe 76, 3-23.

Béland, Daniel, and John Myles (2012). Varieties of Federalism, Institutional Legacies, and Social Policy: Comparing Old-Age and Unemployment Insurance Reform in Canada. International Journal of Social Welfare 21, S75-S87.

Böröcz, József (2000). Informality Rules. East European Politics and Societies 14, 348.

Bunce, Valerie (2005). The National Idea: Imperial Legacies and Post-Communist Pathways in Eastern Europe. East European Politics and Societies 19 (3), 406-442.

Calvert, Randall L. (1995). The Rational Choice Theory of Social Institutions. In Jeffrey S. Banks and Eric A. Hanushek (Eds.), Modern Political Economy. New York: Cambridge University Press, 216-266.

Canache, Damarys (2012). Citizens' Conceptualizations of Democracy: Structural Complexity, Substantive Content, and Political Significance. Comparative Political Studies 45(9), 1132-1158.

Chao, Chien-min and Bruce Dickson (2002). Introduction: Assessing the Lee Teng-hui Legacy. In: Bruce J. Dickson and Chien-min Chao (Eds.), Assessing the Lee Teng-hui Legacy in Taiwan's Politics: Democratic Consolidation and External Relations. Armonk: M.E. Sharpe, 3-26.

Chu, Yun-han and Tse-min Lin (1996). The Process of Democratic Consolidation in Taiwan: Social Cleavage, Electoral Competition, and the Emerging Party 
System. In Hung-mao Tien (Ed.), Taiwan's Electoral Politics and Democratic Transition. Armonk: M.E. Sharpe, 79-104.

Clare, Joe (2007). Democratization and International Conlflict: The Impact of Institutional Legacies. Journal of Peace Research 44 (3), 259-276.

Crawford, Beverly, and Arend Lijphart (1995). Explaining Political and Economic Change in Post-Communist Eastern Europe: Old Legacies, New Institutions, Hegemonic Norms, and International Pressures. Comparative Political Studies 28(2), 171-199.

Collier, David (1991). The Comparative Method: Two Decades of Change. In Dankwart Rustow and Kenneth Paul Erickson (Eds.), Comparative Political Dynamics: Global Research Perspectives. New York: Harper Collins Pubishers, 7-31.

Collier, David and Steven Levitsky (1997). Democracy with Adjectives: Conceptual Innovation in Comparative Research. World Politics 49(3), 430-451.

Costa, A.T.M. (2011). Police Brutality in Brazil: Authoritarian Legacy or Institutional Weakness? Latin American Perspectives 38(5), 19-32.

Costa Pinto, António (2006). Authoritarian Legacies, Transitional Justice and State Crisis in Portugal's Democratization. Democratization 13(2), 173204.

Costa Pinto, António (2010). The Authoritarian Past and South European Democracies: an Introduction. South European Society and Politics 15(3), 339-358.

Czaban, Laszlo and Jeffrey Henderson (1998). Globalization, Institutional Legacies and Industrial Transformation in Eastern Europe. Economy and Society 27(4), 585-613.

David, Paul (2000). Path Dependence, Its Critics, and the Quest for 'Historical Economics. In P. Garrouste and S. Ioannides (Eds.), Evolution and Path Dependence in Economic Ideas: Past and Present. Cheltenham: Edward Elgar.

Diamond, Larry (1996). Is the Third Wave of Democratization over? The Imperative of Consolidation. Journal of Democracy 7(3), 33.

Diamond, Larry (1999). Developing Democracy: Toward Consolidation. Baltimore: The John Hopkins University Press.

Dickson, Bruce J. and Chien-min Chao (Eds.) (2002). Assessing the Lee Teng-hui Legacy in Taiwan's Politics: Democratic Consolidation and External Relations. Armonk: M.E. Sharpe.

Dickson, Bruce J. (2006). The Kuomintang before Democratization: Organizational Change and Constancy. In Hung-mao Tien (Ed.), Taiwan's Electoral Politics and Democratic Transition. Armonk: M.E. Sharpe, 42-78. 
Ekiert, Grzegorz (2003). Patterns of Postcommunist Transformation in Central and Eastern Europe. In Grzegorz Ekiert and Stephen E Hanson (Eds.), Capitalism and Democracy in Central and Eastern Europe: Assessing the Legacy of Communist Rule. Cambridge: Cambridge University Press, 89119.

Ekiert, Grzegorz and Stephen E. Hanson (Eds) (2003a). Capitalism and Democracy in Central and Eastern Europe: Assessing the Legacy of Communist Rule. Cambridge: Cambridge University Press.

Ekiert, Grzegorz and Stephen E. Hanson (2003b). Introduction. In Grzegorz Ekiert and Stephen E Hanson (Eds.), Capitalism and Democracy in Central and Eastern Europe: Assessing the Legacy of Communist Rule. Cambridge: Cambridge University Press, 15-48.

Fell, Dafydd (2005). Party Politics in Taiwan: Part Change and the Democratic Evolution of Taiwan, 1991-2004. Abingdon: Routledge.

Fell, Dafydd (2006). Change and Continuity in Taiwanese Party Politics since 2000. In Dafydd Fell, Henning Klöter and Chang Bi-yu (Eds.), What has changed? Taiwan Before and After the Change in Ruling Parties. Wiesbaden: Harrassowitz Verlag, 21-40.

Fell, Dafydd, Henning Klöter and Chang Bi-yu (Eds.) (2006). What has changed? Taiwan Before and After the Change in Ruling Parties. Wiesbaden: Harrassowitz Verlag.

Foweraker, Joe and Roman Krznaric (2002). The Uneven Performance of Third Wave Democracies: Electoral Politics and the Imperfect Rule of Law in Latin America. Latin American Politics and Society 44(3), 29-60.

Garrouste, P. and S. Ioannides (Eds.) (2000). Evolution and Path Dependence in Economic Ideas: Past and Present. Cheltenham: Edward Elgar.

Geddes, Barbara (1999). What do we know about democratization after twenty years. Annual Review of Political Science 2, 1: 115-144.

George, Alexander L. and Andrew Bennett (2004). Case Studies and Theory Development in the Social Sciences. Cambridge: MIT Press.

Gerring, John (2004). What is a Case Study and What is it Good for? American Political Science Review 98(2), 341-354.

Göbel, Christian (2006). Beheading the Hydra: Combating Political Corruption and Organized Crime in the KMT and DPP Eras. In David Fell, Henning Klöter and Chang Bi-yu (Eds.), What has changed? Taiwan Before and After the Change in Ruling Parties. Wiesbaden: Harrassowitz Verlag, 61-82.

Griffiths, Hugh and Aaron Karp (2008). Ukraine: Coping with Post-Soviet Legacies. Contemporary Security Policy 29(1), 202-228. 
Groves, Tamar (2012). Everyday Struggles against Franco's Authoritarian Legacy: Pedagogical Social Movements and Democracy in Spain. Journal of Social History 46(2), 305-334.

Grzymala-Busse, Anna (2003). Redeeming the Past: Communist Successor Parties after 1989. In Grzegorz Ekiert and Stephen E Hanson (Eds.), Capitalism and Democracy in Central and Eastern Europe: Assessing the Legacy of Communist Rule. Cambridge: Cambridge University Press, 157181.

Grzymala-Busse, Anna (2010). The Best Laid Plans: the Impact of Informal Rules on Formal Institutions in Transitional Regimes. Studies in Comparatice International Development 45, 311-333.

Haggart, Stephan and Robert R. Kaufman (1999). The Political Economy of Democratic Transitions. In Lisa Anderson (Ed.), Transitions to Democracy. New York: Columbia University Press, 72-98.

Hall, Peter H. and Rosemary C. R. Taylor (1996). New Institutionalisms. Political Studies 44, 936-957.

Hanson, Stephen E. (1995). The Leninist Legacy and Institutional Change. Comparative Political Studies 28(2), 306-314.

Helmke, Gretchen and Steven Levitsky (2006). Informal Institutions and Democracy: Lessons from Latin America. Baltimore: The John Hopkins University Press.

Hite, Katherine and Paola Cesarini (2004). Introducing the Concept of Authoritarian Legacies. In Katherine Hite and Paola Cesarini (Eds.), Authoritarian Legacies and Democracy in Latin America and Southern Europe. Notre Dame: University of Notre Dame, 2-24.

Hite, Katherine and Paola Cesarini (Eds.) (2004). Authoritarian Legacies and Democracy in Latin America and Southern Europe. Notre Dame: University of Notre Dame.

Horowitz, Shale (2003). Sources of Post-Communist Democratization: Economic Structure, Political Culture, War, and Political Institutions. Nationalities Papers 31 (2), 119-137.

Hsieh, John Fuh-sheng (2002). Whither the Kuomintang? In Bruce J. Dickson and Chien-min Chao (Eds.), Assessing the Lee Teng-hui Legacy in Taiwan's Politics: Democratic Consolidation and External Relations. Armonk: M.E. Sharpe, 111-129.

Huang, The-fu (1996). Elections and the Evolution of the Kuomintang. In Hungmao Tien (Ed.), Taiwan's Electoral Politics and Democratic Transition. Armonk: M.E. Sharpe, 105-136.

Huntington, Samuel P. (1991). The Third Wave: Democratization in the Late Twentieth Century. Norman: University of Oklahoma Press. 
Inglot, Tomasz (2003). Historical Legacies, Institutions, and the Politics of Social Policy in Hungary and Poland, 1989-1999. In Grzegorz Ekiert and Stephen E Hanson (Eds.), Capitalism and Democracy in Central and Eastern Europe: Assessing the Legacy of Communist Rule. Cambridge: Cambridge University Press.

King, Gary, Robert Keohane and Sidney Verba (1994). Designing Social Inquiry. Princeton: Princeton University Press.

Kopecký, Petr (2001). Parliaments in the Czech and Slovak Republics: Party Competition and Parliamentary Institutionalization. Aldershot: Ashgate.

Kyong-ae, Park and Heng Lee (2005). Democratic Consolidation in the ROK and Political perspectives on the 2002 Presidential Election. In Alexandre Mansourov (Ed.), A Turning Point: Democratic Consolidation in the Republic of Korea and Strategic Readjustment in the U.S.-ROK Alliance. Honolulu: Asia-Pacific Center for Security Studies, 47-62.

Lamounier, Bolivar and Amaury de Souza (1993). Changing Attitude Toward Democracy and Institutional Reform in Brazil. In Larry Diamond (Ed.), Political Culture and Democracy in Developing Countries. London: Lynne Rienner Publishers, 295-326.

Lawson, Kay (1985). The Human Polity: an Introduction to Political Science. Boston: Houghton Mifflin.

Lieberson, Stanley (1994). More on the Uneasy Case for Using Mill-Type Methods in Small-N Comparative Studies. Social Forces 72, 1225-1237.

Lin, Joh-wen (2006). The Politics of Reform in Japan and Taiwan. Journal of Democracy 17(2), 118-131.

Linz, Juan J. (1990). Transitions to Democracy. Washington Quarterly 13, 143164.

Linz, Juan J. and Alfred Stepan (1996). Problems of Democratic Transition and Consolidation: Southern Europe, South America, and Post-Communist Europe. Baltimore: The John Hopkins University Press.

Malle, Silvana (2009). Soviet Legacies in Post-Soviet Russia: Insights from Crisis Management. Post-Communist Economies 21(3) 249-282.

March, James G. and Johan P. Olsen (1984). The New Institutionalism: Organizational Factors in Political Life. The American Political Science Review 78(3), 734-749.

March, James G. and Johan P. Olsen (2006). Elaborating the "New Institutionalism. In R.A.W. Rhodes, Sarah A. Binder and Bert A. Rockman (Eds.), The Oxford Handbook of Political Institutions. Oxford: The Oxford University Press, 322.

Marsh, David and Gerry Stoker (Ed.) (2010). Theory and Methods in Political Science. Basingstoke: Palgrave Macmillan. 
Markovitz, Irving Leonard (1999). Constitutions, the Federalist Papers, and the Transition to Democracy. In Lisa Anderson (Ed.), Transitions to Democracy. New York: Columbia University Press, 42-71.

Mattlin, Mikael (2011). Politicized Society: the Long Shadow of Taiwan's One-Party Legacy. Copenhagen: Nordic Institute of Asian Studies Press.

Meyer, John W. and Brian B. Rowan (1977). Institutionalized Organizations: Formal Structure as Myth and Ceremony. American Journal Of Sociology 83, 340-363.

Miller, Edward Alan and Jane Banaszak-Holl (2005). Cognitive and Normative Determinants of State Policymaking Behavior: Lessons from the Sociological Institutionalism. Publius 35(2), 191-216.

Moody, Peter R. Jr. (1992). Political Change on Taiwan: A Study of Ruling Party Adaptability. New York, Praeger Publishers.

Moody, Peter R. Jr. (2002). Some Problems in Taiwan's Democratic Consolidation. In Bruce J. Dickson and Chien-min Chao (Eds.), Assessing the Lee Teng-hui Legacy in Taiwan's Politics: Democratic Consolidation and External Relations. Armonk: M.E. Sharpe, 27-50.

Morrison, Claudio, Richard Croucher and Olga Cretu (2012). Legacies, Conflict and 'Path Dependence' in the Former Soviet Union. British Journal of Industrial Relations 50(2), 329-351.

Njolstad, Olav (Ed.) (1990). Arms Races: Technological and Political Dynamics. Thousand Oaks: Sage.

Njolstad, Olav (1990). Learning from History? Case Studies and Limits to TheoryBuilding. In Olav Njolstad (Ed.), Arms Races: Technological and Political Dynamics. Thousand Oaks: Sage, 220-46.

O’Donnell, Guillermo (1996). Illusions about Consolidation. Journal of Democratization 7(2), 34-51.

O’Donnell, Guillermo (2007). The Perpetual Crises of Democracy. Journal of Democracy 18(1), 5-11.

Olson, David M. and Gabriella Ilonszki (2011). Two Decades of Divergent PostCommunist Parliamentary Development. The Journal of Legislative Studies 17(2), 234-255.

Palacios Cerezales, Diego (2010). Repressive Legacies and the Democratisation of Iberian Police Systems. South European Society and Politics 15(3), 429448.

Parsons, Craig (2010). Constructivism and Interpretive Theory. In David Marsh and Gerry Stoker (Eds.), Theory and Methods in Political Science. Basingstoke: Palgrave Macmillan. 
Pejovich, Svetozar (1998). Toward a Theory of the Effects of the Interaction of Formal and Informal Institutions on Social Stability and Economic Development: Prepared for the Conference on Formal Institutions and Informal Arrangements in Transformation Societies, University of Potsdam, Germany, October 7 - 9, 1998. Freiburg Discussion Papers on Constitutional Economics 98(2).

Pereira, A.W. (2001). Virtual Legality: Authoritarian Legacies and the Reform of Military Justice in Brazil, the Southern Cone, and Mexico. Comparative Political Studies 34(5), 555-574.

Pierson, Paul (2004). Politics in Time: History, Institutions, and Social Analysis. Princeton: Princeton University Press.

Pop-Eleches, Grigore (2007). Historical Legacies and Post-Communist Regime Change. The Journal of Politics 69 (4), 908-926.

Rhodes, R.A.W., Sarah A. Binder and Bert A. Rockman (Eds.) (2006). The Oxford Handbook of Political Institutions. Oxford: The Oxford University Press.

Rich, Timothy S. (2012). The Effects of Election Reform on Legislator Perceptions: the Case of Taiwan. Japanese Journal of Political Science 13(3), 317-336.

Rigger, Shelley (1999). Politics in Taiwan: Voting for Democracy. London: Routledge.

Robbins, Michael D.H. and Mark Tessler (2012). The Effect of Elections on Public Opinion Toward Democracy. Comparative Political Studies 45(10), 12551276.

Rose, Richard and Doh Chull Shin (2001). Democratization Backwards: the Problem of Third-Wave Democracies. British Journal of Political Science 31(2), 331-345.

Roy, Denny (2003). Taiwan: a Political History. Ithaca: Cornell University Press.

Rustow, Dankwart and Kenneth Paul Erickson (1990). Comparative Political Dynamics: Global Research Perspectives. New York: Harper Collins Pubishers.

Schedler, Andreas (2001). Measuring Democratic Consolidation. Studies in Comparative International Development 36 (1), 66-91.

Schöpflin, George (2000). Nations, Identity, Power. New York: New York University Press.

Searing, Donald D. (1991). Roles, Rules, and Rationality in the New Institutionalism. The American Social Science Review 85(4), 1239-1260.

Shih, Chih-yu (2007). Democracy (Made in Taiwan): The Success State as a Political Theory. Lanham: Lexington Books. 
Shih, Mei-chiang, Milan Tung-wen Sun and Guang-xu Wang (2012). The Historical Institutionalism Analysis of Taiwan's Administrative Reform. International Review of Administrative Sciences 78, 305-327.

Simon, Scott (2010). Negotiating Power: Elections and the Constitution of Indigenous Taiwan. American Ethnologist 37(4), 726-740.

Solinger, Dorothy J. (2001). Ending One-Party Dominance: Korea, Taiwan, Mexico. Journal of Democracy 12(1), 30-42.

Stockton, Hans (2010). How Rules Matter: Electoral Reform in Taiwan. Social Science Quarterly 91(1), 21-41.

Svolik, Milan (2008). Authoritarian Reversals and Democratic Consolidation. American Political Science Review 102 (2), 153-168.

Tien, Hung-mao (1996). Elections and Taiwan's Democratic Development. In Hung-mao Tien (Ed.), Taiwan's Electoral Politics and Democratic Transition. Armonk: M.E. Sharpe, 3-26.

Tien, Hung-mao (Ed.) (1996).Taiwan's Electoral Politics and Democratic Transition. Armonk: M.E. Sharpe.

Toole, James (2003). Straddling the East-West Divide: Party Organisation and Communist Legacies in East Central Europe. Europe-Asia Studies 55(1).

Valenzuela, Arturo (1995). Chile: The Origins, Consolidation, and Breakdown of a Democratic Regime. In Larry Diamond, Juan J. Linz and Seymour Martin Lipset (Eds.), Democracy in Developing Countries: Latin America. Boulder: Lynne Rienner, 67-118.

Weber, Max (1922). Economy and Society: an Outline of Interpretive Sociology. Translated by Guenther Roth and Claus Wittich (1978). Berkeley: California University Press.

Zhu, Yunhan, Larry Jay Diamond, and To-chull Sin (2001). Halting Progress in Korea and Taiwan. Journal of Democracy 12(1), 122-136. 